\title{
Peace Building Mechanism: Alternative to Dispute Resolution. A Study of Calabar, Nigeria.
}

\author{
${ }^{1}$ Usang, ${ }^{2}$ Eteng Eloma \\ ${ }^{I}$ Faculty of Education Cross River University of Technology, Calabar \\ ${ }^{2}$ Barrister Ngozi Fred C.Ugwumba Open University of Nigeria, Calabar Campus
}

\begin{abstract}
This study focuses on peace building mechanism as an Alternative to Dispute Resolution. It sought to establish how the people of Calabar, in southern Nigeria have used it as an effective indigenous peace building mechanism to prevent, mitigate, manage, and resolve conflicts, and to draw the attention of the governments as to streamline its use as an indigenous mechanism to make the country stable and peaceful. The study was conducted in Calabar Municipal Council of Cross River State, Nigeria. The methodology used in this research was collection of information from primary sources through interviews and questionnaire administration as well as from secondary sources through library research and internet. The data used for the project were the responses of teachers, council staff and traditional rulers randomly selected from the research area. The Mean and Simple Percentage Method formulae were used to analyze the data and interpret the results. The results revealed that the people of Calabar have developed widely used and effective indigenous mechanisms for the prevention and resolution of conflicts. The study concluded that there are latent political and socio-cultural conflicts threatening the peace of Cross River State; and recommended that these indigenous preventive mechanisms should be recognized and backed by law to complement the efforts at resolving disputes in Nigeria.
\end{abstract}

\section{Introduction}

Peace has remained the most valued and indeed the greatest human need in history. Aristotle calls it the essence of human existence; and the world has never relented in the quest for peace and the termination of conflict. The 1648 treaty of peace in Westphalia which ushered in the modern nation state structure of political entities can be legitimately termed the real first attempt at securing planetary peace by mankind. The Congress of Vienna (1814-1815), the League of Nations (1918-1939) and now the United Nations (1945); are international efforts to achieve the goal of a collective security for humanity. Agwu (2007: xx) noted that the search for world peace is a persistent and interminable task; which unfortunately, has been consistently and tragically marred at the very critical junctures of their efforts.

Conflict is as old as creation and it the greatest enemy of peace but a uniquely unavoidable part of man. It impinges on reality and attempts to infest all human actions. Sometimes, it is experienced within the individual or between individuals, and sometimes among groups, states and even transcends to other creatures. The fact that this phenomenon exists in all creation makes it difficult to understand.

When conflict is resolved, there is bound to be peace. Conflict and peace have been subjects of investigations in political science, sociology, economics, psychology and other human sciences. The major concern has been how to give meaning to this phenomenon, diagnose its structures, locate its causes and attempt to find solutions and achieve peace. In spite of all the efforts, conflict appears to defy solutions by drawing individuals at dagger points, group as well as institutions at war and national at loggerheads. It has been of central concern not only to these categories but also to the national community and development agencies. While it has been a herculean task to terminate conflicts, the international system successfully prevented a third world war.

The absence or lack of conflict management or peace building mechanisms in the early years of the Federation resulted in the 1967 Nigerian civil war. Though unable to terminate conflict, the Nigerian Federation rose to the challenge and successfully established effective peace building mechanisms that have prevented any other civil war in the country and held the federating units together for 43 years now. Despite the country's recent relief from the Niger Delta insurgency, Nigeria is today faced with the challenge of Boko Haram. The causes of these crises in the Nigerian Federation have been fundamentally ethnic religion and politically based. Cross River State, like other states in Nigeria, has some conflict issues and the state recently joined the Federal Government of Nigeria in establishing the Multi-door Courthouse as an Alternative Dispute Resolution (ADR) mechanism.

\section{Statement Of The Problem}

Cross River State is popularly acclaimed the most relatively peaceful state in the Nigerian Federation. The State is not, however, absolved of internal strives. Apart from the several escalated but resolved communal 
disputes, there are some obvious political and socio-cultural differences currently threatening the peace of the State. The State has joined the rest of the world in employing the Multi-door Courthouse as an Alternative to Dispute Resolution mechanism; but needs to adopt peace building mechanisms as a proactive approach to addressing these threats, prevent conflicts escalation and protect its status as the most peaceful part in Nigeria.

\section{Research Hypotheses \\ 1. Indigenous peace building mechanisms are not effective and widely accepted for the prevention and resolution of conflicts in Nigeria.}

\section{Significance Of The Study}

This study will contribute to the existing literature on the importance of peace building in conflicts prevention, the departments of Peace and Conflict Studies and political Science in general. It will further generate agitation in the minds of would-be readers and spur further research works on this subject. The findings and recommendations of this study would also improve the preventive mechanisms and management of conflicts-related development challenges in Calabar and other flashpoints in Nigeria.

\section{Theoretical Framework}

Theories of social conflict revolve around the recognition that the world of science is delineated into the natural world and the social world - physical/natural and social/behavioural sciences. Okeibunor and Anugwom, (2003:3) noted that social theories help social scientist to understand, explain and predict the social world around her. The social scientist, more or less perceive a theory as, logically interconnected set of propositions from which empirical uniformity can arise. This study adopts the social conflict theories on peace in the explanation of its subject matter.

\section{Social Conflict Theories}

Social conflict theories are the outcome of the rejection of the consensus or inherently stable model of the social world offered by the functionalists or systems theorists. The theories put forward the notion that conflict is a fundamental part of social life, and can never be totally eradicated. Max Weber insisted that conflict cannot be excluded from social life. Criminologist, George Vold (1958) sees social conflict as part and parcel of the dynamics of society, adding, however, that society is built both on reasonable consensus (which explains progress or growth) and on endless conflict or dissension (which explains change and progress).

In all their arguments, social conflict theories are in consensus that conflict has an intrinsic relationship with peace. Lewis Coser (1980:232) particularly accepts that conflicts take different forms, and peace is nothing more than a change in the form of the conflict. Boulding (1978); Galtung (1985), Rappoport (1992); Vasquez (1993) pointed out that peace does not mean the absence of war but rather signifies that there are institutional means of non-violence management of conflict.

\section{Literature Review}

Norwegian sociologist Johan Galtung first created the term peace building in the 1970s, through his promotion of systems that would create sustainable peace. Such systems needed to address the root causes of conflict and support local capacity for peace management and conflict resolution. Galtung's work emphasized a bottom-up approach that decentralized social and economic structures, amounting to a call for a societal shift from structures of coercion and violence to a culture of peace. American sociologist John Paul Lederach (1997: 75) proposed a different concept of peace building as engaging grassroots, local, Non Governmental Organization, international and other actors to create a sustainable peace process.

Peace building has since expanded to include many different dimensions, such as disarmament, demobilization and reintegration and rebuilding governmental, economic and civil society institutions. The concept was popularized in the international community through a one time UN Secretary-General Boutros Boutros-Ghali's January 31, 1992 report: An Agenda for Peace. At the 2005 World Summit, the United Nations began creating a peace building architecture based on Kofi Annan's proposals. The proposal called for three organizations: the UN Peace building Commission, which was founded in 2005; the UN Peace building Fund, founded in 2006; and the UN Peacebuilding Support Office, which was created in 2005. These three organizations enable the Secretary-General to coordinate the UN's peace building efforts.

National governments' interest in the topic has also increased due to fears that failed states serve as breeding grounds for conflict and extremism and thus threaten international security. Some states have begun to view peace building as a way to demonstrate their relevance. However, peace building activities continue to account for small percentages of states' budgets.

Reychler (2001: 18) noted that there is obvious awareness today that a great deal of human suffering is linked to violent conflicts, political instability, or unjust policies and practices. Short-term humanitarian relief 
and crisis intervention, while important, are not enough in conflict or post-conflict societies. There is greater increasing awareness of the need for proactive measures to nip violent conflicts in the bud; and where violence has erupted, pursue post-armed-conflict reconciliation, development of capacity for conflict resolution and management, and the building of sustainable peace. Lederach (1997: 75) supports this position and opines that it is generally agreed that the central task of peace building is to create positive peace, a "stable social equilibrium in which the surfacing of new disputes does not escalate into violence and war." Sustainable peace is characterized by the absence of physical and structural violence, the elimination of discrimination, and selfsustainability. Moving towards this sort of environment goes beyond problem solving or conflict management. Peace building initiatives try to fix the core problems that underlie the conflict and change the patterns of interaction of the involved parties. They aim to move a given population from a condition of extreme vulnerability and dependency to one of self-sufficiency and well-being.

Boutros-Ghali (1992) argues that the popular adage has it that 'prevention is better than cure'. Given the heavy and enduring costs of armed conflicts, there is no disputing the fact that making efforts to prevent them from breaking out in the first place is better than waiting until it is too late. This makes the main aims of conflict prevention as being 'to seek to identify at the earliest possible stage situations that could produce conflict, and to try through diplomacy to remove the sources of danger before violence results' The strategy here he says entails two things: conflict prevention measures and early warning systems. He defined conflict prevention measures as pre-peace building mechanisms that could effectively address the root causes of a conflict before it turns violent, while the early warning systems aim to identify threats to these elements so that effective conflict prevention measures can be taken. In other words, ensuring 'human security' is the thrust of the former, while the latter serves as a surveillance camera for any deficit in providing the different components of this human security'.

\section{Early Warning Systems}

The earlier a dispute or a conflict can be identified, diagnosed and its causes properly addressed, the less likely it is that the situation will deteriorate into violence. Normally, armed conflict does not occur suddenly without warning indicators. Thus, in order to guarantee the sustainability of the conflict prevention measures identified above, governments and regional, as well as international organisations must ensure that there are proper mechanisms for conflict early warning in place, based on information gathering and informal and formal fact-finding.

\section{Indigenous Agents Of Peacebuilding}

Lederach (1997: 94) believes that the greatest resource for sustaining peace in the long term is always rooted in the local people and their culture. Parties should strive to understand the cultural dimension of conflict, and identify the mechanisms for handling conflict that exist within that cultural setting. Building on cultural resources and utilizing local mechanisms for handling disputes can be quite effective in resolving conflicts and transforming relationships. Initiatives that incorporate citizen-based peacebuilding include community peace projects in schools and villages, local peace commissions and problem-solving workshops, and a variety of other grassroots initiatives.

Assefa Abebe (2013) too remarks that since the causes of conflict are different, it would be better to use different mechanisms for the prevention and resolution of conflicts. Therefore, more than anybody else governments, whose main duty is maintenance of peace and security, are responsible for providing their respective peoples with alternative conflict prevention and resolution mechanisms, popular and widely used among these are the indigenous agents. He adds that indigenous mechanisms are time tested and effective to handle conflicts. Michelle Maiese (September 2003) opines that researchers and practitioners also increasingly find that peace building is most effective and durable when it relies upon local conceptions of peace and the underlying dynamics which foster or enable conflicts. In Calabar, like other parts of Nigeria, popular indigenous agents have not only functioned as peace building mechanisms and ADR but have effectively prevented violent conflicts in the land. These include the EKPE Society and the grade system.

\section{Ekpe Society And Age-Grade System}

The EKPE Society and the grade system, as provided by Rosalind I. J Hackett (pp 31-36), constituted an effective and widely respected agent of peacebuilding or means of social control among the Efiks of Cross River State. The history of Ekpe society is shrouded in mystery since many members pledge a vow of silence. The Ekpe Society is a religious and cultural institution among the Efik people, it can also be found among the Annang and the Ibibios. The term Ekpe in Efik means leopard, an animal considered invisible and mysterious in Efik and Ibibio folklore. The society then was an esoteric cult in which the uninitiated knew little about. Members of the Ekpe society are said to act as messengers of the ancestors (ikan). Only males can join, boys being initiated about the age of puberty. Members are bound by oath of secrecy, and fees on entrance are 
payable. Ekpe members always wear masks when performing their police duties, and although individuals may nonetheless be recognized, fear of retribution from the ikan stops people from accusing those members who may overstep their limits.

Structurally, the Ekpe society had two main grades, for promotion to each of which fresh initiation ceremonies, fees and oaths are necessary. The higher grade was comprised of members of the Nyamkpe, Okpoho, Okuahama, Nakanda and the lower grades were made up of Mboko, Mboko Mboko, Mkpe, Mbakara and Edibo. The society was an open but secret society accepting free men, slaves and women. However, the higher grade was generally limited to those who could pay its high fees. The society is now seen as a fraternity along the masonic lines which tries to represent the interest of Efiks.

At its peak, Ekpe society permeated the social, economic and political life of the Efiks. The society used its power to enforce law and order through fear. It combines a kind of freemasonry with political and law enforcing aims. For instance any member wronged in an Ekpe district, that is one dominated by the society, has only to address an Ekpe-man or beat the Ekpe drum in the Ekpe-house, or blow Ekpe as it is called, i.e. sound the Ekpe horn, before the hut of the wrong-doer, and the whole machinery of the society is put in force to see justice done. During the emergence of the trans Atlantic trade, the Ekpe members transformed themselves into a trading and regulatory organization enforcing commercial laws and engaging in commerce. But lately its dominance has been eroded as urbanization and modern political administration expanded.

\section{Advantages Of Indigenous Peacebuilding Mechanisms}

Asebe (2013) again argues that when compared with the non-indigenous ones, indigenous mechanisms for the prevention and resolution of conflicts are less complex, save time, and give a chance to parties in conflict to actively participate to solve their own problems and to handle their affairs in a relatively more acceptable way to them. Indigenous mechanisms are popular and they are widely used in almost all communities in Nigeria. They have different advantages including, but not limited to, the following:

1. Quick response to crisis; reduce regular court caseloads, and saves public money.

2. Given the shortage of judges who work in the regular courts and budget constraints, they are complementary to the modern government structures and are not substitutes or competitors as some government officials think and worry about.

3. They give access to many people who do not find the modern system of conflict resolution comfortable, affordable or suited to their need.

4. Disputants are satisfied with their operations and view their outcomes as fair because these mechanisms give a chance to the parties to actively participate in handling their affairs.

\section{Latent Conflicts In Cross River State}

Cross River State has recorded cases of conflicts escalation in the form of inter communal disputes. Some of these skirmishes include the boundary disputes between Ntan-Obu in Odukpani Local Government of Cross River State and Ikpa-Nya-Ibiono in Akwa Ibom State as well as the Adadama in Abi LGA of Cross River State and Igwo, Ebonyi State. The other internal disputes are between Ugep and Idomi in Yakurr Local Government, Ebom and Ebi-Jakara, Oyadama and Nko, Boje and Nsadop, Boki and Mbube, Ekuri and Yala, and that of Oyadama and Inyima. The State has always used the existing conventional legal systems to resolve most of these threats. However, the state still harbours some latent socio-political and cultural conflicts capable of threatening the peaceful coexistence of the constituents. There is the succession dispute to the throne of theObong of Calabar, the allocation of political positions and management of electoral processes as well as other civil and commercial conflict challenges lingering in the judiciary.

\section{Methodology Research Design}

This research was a cross-sectional survey based on expo facto design. According to Odo (1992:28) a survey study is cross-sectional when it involves more than one community or organization or locality or state or nation and a sample is taken from the population and studied. The study examined the importance of peace building as an ADR mechanism in Cross River State of Nigeria. The survey method were employed because of its large population, Cross River State of Nigeria, is described using the probability proportionate to size technique

\section{The Research Area}

The research area in this study is Calabar (also referred to as 'Canaan City'). It is a city in Cross River State, one of the south-south states of Nigeria. The city is watered by the Calabar and Great Kwa Rivers and 
creeks of the Cross River (from its inland delta). Calabar is the capital of Cross River State. For the purpose of administration, the city is divided into Calabar Municipal and Calabar South local government areas. It has an area of $406 \mathrm{~km}^{2}$ and a population of 371,022 at the 2006 census. The city once served as the seat of Government of the Niger Coast Protectorate, Southern Protectorate and Oil River Protectorate. It is thus effectively the first Nigerian capital city.

\section{History}

The original town was known as Atakpa. Calabar is a large metropolis today with several towns like Akim, Ikot Ansa, Ikot Ishie, Kasuk, Duke Town, Henshaw Town, Ikot Omin, Obutong, Bakassi, Biase, Akamkpa, etc. As far back as the 16th century, Calabar had been a recognized international sea port, shipping out goods such as palm oil. During the era of the Atlantic slave trade it subsequently became a major port in the transportation of African slaves. Most slave ships that transported slaves from Calabar were English, at around 85\% of these ships being from Bristol and Liverpool merchants. Old Calabar (Duke Town) and Creek Town, 10 miles northeast, were crucial towns in the trade of slaves in that era. The first British warship to sail as far as Duke Town, where she captured seven Spanish and Portuguese slavers, may have been HMS Comus in 1815.

\section{Political Authority}

Calabar has three principal landlord kingdoms, namely the Qua Kingdom of ejagham (Ekoi)/bantu origin, the Efut and the Efik Kingdoms. The Qua Kingdom has the Ndidem of the Qua nation as the Grand patriarch,The Efut have the Muri munene as the grand patriarch while the Efik Kingdom partriarch is knowns as the Obong. The Efik political authority as it concerns the Obong is hinged on a political tripod, Creek Town, made up of Ambo, Cobham and Eyo; Old Town made up of Obutong; and, Duke Town or Atakpa made up of Duke/Archibong, Eyamba, Ntiero, Henshaw and Cobham. Each leg of this tripod at one time or the other was ruled by a separate Obong. Within the last 100 years, a gentleman's agreement to merge these three zones into one, with a single titular head as the Obong, and the distribution or opening up of the title to all Efik wards, was arrived at. It is the attempt to do away or dishonor this 'contract of understanding' that is at the root of the Obong of Calabar crises. Each of the aspirants to the throne is eminently qualified, none no more so, than the other. The title of the Obong of Calabar had been held by Nsa Effiom and Ekpo Nsa in the 17th century, these two gentlemen were from the Henshaw[disambiguation needed] ward. Attempts by the Henshaw to have an Obong resulted in a war in 1870. The Henshaws did not attain this title again until the last 50 years when David Henshaw became Obong. Cobham Town where Bassey Ekpo Bassey hails from had their first and only Obong recently. All these were made possible because of 'the contract'.

\section{Calabar Kingdom And People}

Before the colonial period, Calabar, originally known as Akwa Akpa, was a Kingdom with the City of Calabar as the site of government, the Obong of Calabar as the ruler and the Ekpe Secrete Society, as the stool on which the Obong of Calabar sat. The other kingdoms in Calabar are that of the Qua Nation with the Ndidem of the Quas and paramount ruler of calabar municipality and the Muri Munene of Efut and paramount ruler of calabar south. Calabar people are mainly people from the Greater Calabar district - Calabar South, Calabar Municipality, Akpabuyo, Bakassi, Biase, Odukpani and Akamkpa, but as commonly used in Nigeria, the term Calabar People could also refer to both the indigenes of Greater Calabar as well as the people of the original South Eastern State of Nigeria which is at present the people of Akwa Ibom State and Cross River State.

\section{Method Of Data Analysis}

The data collected from eight questionnaires were analyzed using the Simple Percentage and Mean Methods. The data were scored using the Linkert Scale Rating. A score of 45 was assigned to all Strongly Agree responses and 35 to all Agree responses. Disagree and Strongly Disagree responses were assigned 25 and 15 scores respectively. Based on this, a cut off score of 30, representing $25 \%$ was computed as follows:

$$
4=30 \quad 120=\frac{45+35+25+15}{=25 \%}=\underline{30 \times 100}
$$

This obtained percentage mean formed the standard of accepting or rejecting any item of the questionnaires as any item that attracted a mean response of $25 \%$ and above was accepted while those below the mean were rejected.

\section{Data Analysis}

The entire variable response data are analyzed using the simple percentage and Mean methods to examine the three hypotheses formulated to guide the study. 
HYPOTHESIS 1: "Indigenous peace building mechanisms are not effective and widely accepted for the prevention and resolution of conflicts in Cross River State". There was an 100\% respondents agreement on the collated data, this therefore shows a total rejection of the null hypothesis meaning that indigenous peace building mechanisms, like the Ekpe Society, are effective and widely accepted for the prevention and resolution of conflicts amongst the Efiks of Cross River State.

Similarly, Vangauurd Newspaper (February 11, 2012) also reported that the Calabar High Court declaration of the seat of Obong of Calabar vacant when Obong Edidem Ekpo Okon Abasi Otu was still alive attracted the wrath of some Efiks. Apart from invocation of the fore fathers, the women of the Efik stock threatened to protest naked if what they described as the desecration of the land continues. Efik sons and daughters embarked on procession with the 'ekak' masquerade, which appears only in times of travails, difficulties, weeping or mourning. The report added that if there is anything the Efiks of Cross River State cherish most, it is the royal throne of Obong of Calabar. The position of the Obong is among the few traditional institutions in the country that are recognized as first class Chiefs. It is in the same rank with the Oba of Benin, the Sultan of Sokoto, the Emir of Kano, the Oni of Ife and the Obi of Onitsha just to mention a few.

\section{Discussion Of Results}

The result of the hypothesis reveals that indigenous peace building mechanisms, like the Ekpe Society, are effective and widely accepted both for conflicts prevention and resolution of conflicts. Asebe believes that the people of Calabar have developed widely used and effective indigenous mechanisms for prevention and resolution of conflicts. These are negotiation or compromising mechanisms; Reconciliation mechanism, administered by the community elders; Judicial or administrative and political mechanisms; and the religious or adjudication mechanism. These mechanisms give access to many people who do not find the modern system of conflict resolution comfortable, affordable or suited to their need. Disputants are satisfied with their operations and view their outcomes as fair because these mechanisms give a chance to the parties to actively participate in handling their affairs.

This study argues that to effectively address the root causes of a conflict before it turns violent, the threats have to be identified so that effective conflict prevention measures can be taken. The study demonstrates that 'human security' drives conflict prevention, while early warning systems allow surveillance of human security components. It concludes that to protect the popular image of Cross River State as the most peaceful part of Nigeria, government needs to encourages the local peace building measures.

\section{Summary, Conclusion And Recommendations}

\section{Summary}

This research study was a descriptive survey based on expo facto design. The main purpose of the study was to examine the importance of indigenous peace building mechanisms in conflict prevention and an Alternative Dispute Resolution, with Calabar Municipal Council of Cross River State as a case study. To achieve this, the study highlighted some latent conflicts in the state; considered the role of Ekpe society. The data collected were analysed using the Mean and Simple Percentage methods. The results of the analysis revealed that indigenous peacebuilding mechanisms are effective and widely accepted conflicts prevention mechanism that can adequately compliment modern conventional courts and ADRs. The research instrument was both primary and secondary data. The primary data was a four-item questionnaire while the secondary data was unstructured interviews, libraries and internet.

\section{Conclusion}

There are latent political and socio-cultural conflicts in the state that require careful management. There are also time tested and effective indigenous peacebuilding mechanisms, like the Ekpe Society of the Efiks, to prevent, mitigate, manage, and resolve conflicts in Cross River State. The State government needs to streamline and use these indigenous mechanisms to make the state more stable and peaceful.

\section{Recommendations}

Therefore, these indigenous mechanisms for the prevention and resolution of conflict will continue to operate parallel with modern government structures as they have been doing for years. Thus, it would be better if government officially recognize, revitalize and empower these mechanisms and use them as alternative for conflict prevention, mitigation, and resolution. To revitalize and to make these indigenous mechanisms for the prevention and resolution of conflicts more effective, it is necessary to consider the following recommendations and/or policy implications:

Capacity Building: The nature and causes of conflicts are changing from time to time. To analyse the causes of these conflicts and come up with lasting solutions for recurring causes, it is necessary to enhance the capacity of 
local peacemakers through training and experience sharing tours and workshops. These trainings and workshops should focus on increasing conflict management skills, enhancing capacity to analyse information related to conflicts, and narrowing down social distance among the members of different ethnic and religious groups.

Establishing Conflict Management Fund. For these mechanisms to function effectively and other activities, the local peacemakers need money to respond to conflicts on time. Therefore, establishing conflict management fund that can be used to cover the cost of the activities of local peacemakers is very important.

Empowerment. The indigenous mechanisms for the prevention and resolution of conflict have been in operation for centuries. The Government should empower the local councils to establish or give official recognitions to religious and customary courts to adjudicate disputes relating to personal and family laws. Governments at all levels should be mandated to recognize that these indigenous mechanisms will assist the regular court system to reduce court caseloads and contribute to saving of public money; rather than see them as competitor. Policies that encourage these indigenous mechanisms should be advocated. These mechanisms should be accorded necessary legal backing to complement the regular courts in resolving conflicts.

\section{References}

[1]. Abebe, A. (2010). "Indigenous Mechanisms for the Prevention and Resolution of Conflict: The Experience of the Oromo in Ethiopia". Expert meeting on implementing research and innovation policy at policy and institutional levels in Africa. Addis Ababa, Ethiopia

[2]. Agwu, F.A. (2007). "World Peace Through World Law: The Dilemma of the United Nations Security Council". University Press Ltd, Ibadan.

[3]. Benge, G. (1999). "Mary Slessor: Forward into Calabar" (Christian Heroes: Then \& Now). YWAM Publishing.

[4]. Boutros-Ghali, Boutros. (1995). "An Agenda for Peace". New York: United Nations

[5]. Coser L. (1976). "Sociological Theory" (4 $4^{\text {th }}$ Edition). NY and London: Macmillan Pub.

[6]. Crossriverwatch http://www.crossriverstate.gov.ng/ (November 6, 2013)

[7]. Deng, F.M. and I.W. Zartman, (1991). "Conflicts Resolution in Africa". The Brooklyn's

[8]. Doyle, M. and N Sambanis. "Building Peace: Challenges and Strategies after Civil War," The World Bank Group. [available at: http://www.chs.ubc.ca/srilanka/PDFs/Building/ \%20peace-challenges\%20and\%20strategies.pdf]

[9]. Eleojo, E., (2011). "The Growth of Alternative Dispute Resolution in Nigeria". StudyMode.com. Retrieved 05, 2011, from http://www.studymode.com/essays/The-Growth-Of-Adr-In-Nigeria-701815.html

[10]. Francis, D.J. (2006). "Peace and Conflict studies: An African Overview of Basic Concepts" in S.G. Best (ed.) Introduction to Peace and Conflict Studies in West Africa. Ibadan: Spectrum Books Limited.

[11]. Hackett, Rosalind I. J. (1989). "Religion in Calabar: The Religious Life and History of a Nigerian Town". Walter de Gruyter. ISBN 3-11-011481-X.

[12]. Hackett, Rosalind I. J. (1989). "Religion in Calabar: The Religious Life and History of a Nigerian Town". Walter de Gruyter. ISBN 3-11-011481-X.

[13]. Imobighe, T.A. et al (2002). "Conflict and instability in the Niger Delta: The Warri Case, Ibadon: Spectrum Books Ltd.

[14]. Institute Pub., Washington DC.

[15]. Lederach, J. P. (1997). Building Peace: Sustainable Reconciliation in Divided Societies. (Washington, D.C., United States Institute of Peace.

[16]. Maiese, M., (September 2003).

[17]. Oddiri, E. R., (2004). "Alternative Disputes Resolution" at the Annual Delegates Conference of the Nigerian Bar Association. Abuja.

[18]. Offoboche, M., (2015). Those Talking About Ogoja-Calabar Accord Are Ignorant”. crossriverwatch admin. (November 6, 2013)

[19]. Okpa, O., (2011). “Alternative Dispute Resolution Method: Does It Make Sense For Nigeria?” Dallas, Texas.

[20]. Reychler, L., (2001). "From Conflict to Sustainable Peacebuilding: Concepts and Analytical Tools," in Peacebuilding: A Field Guide, Luc Reychler and Thania Paffenholz, eds. (Boulder, Colorado: Lynne Rienner Publishers, Inc.

[21]. Rosalind I. J Hackett. "Religion in Calabar: The Religious Life and History of a Nigerian Town", Walter de Gruyter. ISBN 0899253946

[22]. SAIS, "The Conflict Management Toolkit: Approaches", The Conflict Management Program, Johns Hopkins University [available at: http://www.sais-jhu.edu/resources/middle-east-studies/conflict-management-toolkit

[23]. Sani, S., (2007). "The killing Fields: Religious violence in Northern Nigeria", Ibadan, Spectrum Books Limited.

[24]. Sowe, O., (2011). "Conflict Prevention Mechanisms: Mediation and Preventive Diplomacy", Africa, Gambia.

[25]. Ukpong, O., (2013). “A Brief History of the Efiks", The Efik National Association USA Inc, Detroit, MI 48328 (313) $320-0742$.

[26]. Vangauurd Newspaper (February 11, 2012).

[27]. Vold G., (1958). “Theoretical Criminology”. New York: Oxford University Press. 